\title{
Response of Pimpinella anisum L. Plant For Graphite and Silica Nanoparticles
}

Fardous A. Menesy ${ }^{1}$, M. M. Khalfallah ${ }^{1}$, Nahed M. Rashed $^{2 *}$ and A. K. Maaty ${ }^{3}$

${ }^{1}$ Horticulture Dept., Fac. of Agric. Khafr-Elsheikh Univ., Khafr-Elsheikh, Egypt

${ }^{2}$ Vegetable and Ornamental Department, Faculty of Agriculture, Damietta University,

Damietta, Egypt and ${ }^{3}$ Horticulture Research Institute. Agricultural Research Center,

Giza, Egypt.

$\mathbf{T}$

HERE has been a rising demand for nanotechnology-based products in recent years, particularly in agriculture application. In this effort, the phytotoxicity and stimulatory effects of graphite and silica nanoparticles (NPs) on seed germination, yield characteristics, chemical conformation and root anatomical characteristics of (Pimpinella anisum L.) cv. anise were studied. Seeds were soaked in six concentrations of the two NPs $(0,20,40,60,80$ and 100 $\mathrm{ppm}$ ) for $24 \mathrm{hr}$ to investigate germination under laboratory conditions. The same concentrations were used for soaking and foliar application in the open field. The results displayed that silica NPs improved seed germination traits comparing with graphite NPs. Silica NPs at 20 and $40 \mathrm{ppm}$, showed the highest germination parameters for anise seeds. The increase in germination \% reached $21.88 \%$. Meanwhile, $80 \mathrm{ppm}$ silica NPs enhanced the seeds yield fed. ${ }^{-1}$ by $64.8 \%$, Number of umbels by $50 \%$, root diameter plant ${ }^{-1}$, epidermis thickness and cortex thickness. Silica NPs (60ppm) increased biochemical characteristic. Otherwise, graphite NPs (80ppm) enhanced volatile oil \% and root vascular cylinder thickness. In general, there was a considerable response by anise seeds to graphite and silica nano-sized presenting the possibility of a new methodology to overcome problems with seed germination and increasing the oil percent in some plant species, mostly medicinal plants.

Keywords:Graphite NPs, Silica NPs, Anise, Seeds germination, Yield, Essential oil, Root anatomical characteristics.

\section{Introduction}

Nano-agriculture involves the employment of nanoparticles in agriculture, with the particles imparting specific beneficial effects to the crops (Morla et al., 2011). Among the nanoparticles, nano-silicon has had a special consideration mostly in the last few years. Silicon is an abundant element in the soils which accounts for approximately $32 \%$ of the total weight of the soil and has been known as a beneficial nutrient for growth and development of most plants (Khodakovskaya et al., 2009, Siddiqui and AlWhaibi 2014 and Abdel Latef \& Tran, 2016), but silicon still failed to get assessment as a necessary nutrient for plant growth and development, while favorable belongings of this element have been determined in a wide variety of plant species as a physic mechanical barrier, and is deposited on the epidermal cell walls and leaf sheath, vascular tissues of the stem and hull in most plants particularly monocots (Saqib et al., 2008 and Pei et al., 2010). Silicon has had a very important role in a lot of metabolic and physiological plant activities, for example keeping plant cells turgid and plant size by improving water use efficacy and leaf relative water content. Implementation of silicon fertilizers in silicon-deficient soil can promote plant growth, increase plant resistance to disease, cold and heavy metals such as copper, aluminum, manganese, and iron consequently encourage photosynthesis (Guo, 2000 and $\mathrm{Hu} \&$ Schmidhalter, 2005).

In the recent years, carbon nanomaterials are used in agriculture to rise the crop production. As an important category of carbon nanomaterials such as fullerenes, graphene carbon nanotubes, known for their light weight, super strength and extreme conductivity occupy a unique place in applications of agriculture through their effects on germinations of the seeds, seedling growth, and plant development of various plant species. Similarly Khodakovskaya et al. (2009) found that 
carbon nanotubes $(10-40 \mu \mathrm{g} / \mathrm{ml})$ improve seed sprouting and root development by penetrating the thick coat of tomato seeds and support water uptake inside seeds. In addition, the expression of the tobacco aquaporin (NtPIP1) gene, as well as the production of the (NtPIP1) protein considerably increases in the cells which treated with carbon nanotubes (Khodakovskaya et al., 2012). While, they are known to be beneficial in seed germination, root growth, and photosynthesis. Although, the quick development that occurred in the synthesis and use of carbon nanoparticles, but till now the mode of action of these materials of interaction with the plant is not completely understood because opposite reports from various quarters have been received (Canaset al., 2008 and Lin et al., 2009).

Seed germination is an important phenomenon in modern agriculture because it is a thread of plants lives that guarantee its survival and used as acute phytotoxicity test with numerous benefits like sensitivity, low cost, simplicity, and suitability for unstable chemicals or samples (Wang et al.,2005). Recently, some chemical constituents were applied in a wide range for enhancing seed germination and overcoming seed dormancy problem in plants. Applications of nanomaterials can accelerate plant germination/ production, affect plant protection, above of that help in decrese environmental contaminations as compared with the traditional methods (Khotet al., 2012). Nanoparticles improve the chemical and physical properties of the soil which reflected on plant growth (Amin et al., 1999).

Pimpinella anisum L. (anise) Fam: Apiacea is one of the most important annual medicinal plants, white-flowered, about $44 \mathrm{~cm}$ high, a native of Iran, Turkey, Egypt, Greece, Crete and Asia Minor. Its main active components are used in pharmaceutical industries and cosmetics besides its use as flavoring materials in food stuffs (Nabizadeh et al., 2012). The seeds contain volatile oil and active constituents specially anethole that has been used in pharmaceutical and food products (Klaus et al., 2009). The influence of NPs on plants differs from plant to another and from species to others. However, poor seed germination is a common occurrence in medicinal and aromatic plants especially, seeds after dry storage often display slow and nonuniform germination due to compromised vigor. Moreover, germinating seeds and young seedlings are susceptible to dehydration stress due in part

J. Sus. Agric .Sci. 44, No.1 (2018) to the progressive loss of desiccation tolerance upon seed hydration. As above mentioned, this study was done to examine the effect of $\mathrm{SiO}_{2}$ and graphite NPs concentrations on anise seed germination, yield characteristics, chemical composition, oil productivity and root anatomical characteristics.

\section{Materials and Methods}

The experiments were performed during the two seasons of 2013-2014 and 2014-2015.

\section{Laboratory experiment}

This experiment was carried out in the lab of Sakha Horticulture Research station, Kafr ElSheik Governorate, Egypt to study the germination characteristics. Local variety of healthy anise seeds from Medicinal and Aromatic plants Department, Agricultural Research Center, Egypt were surface sterilized by dipping them in sodium hypochlorite (5\%) solution for $5 \mathrm{~min}$, washed more than one time with tap water then rinsed with distilled water, and dried by blotting in filter paper. The sterilized seeds were divided into six portions. Equal portions of sterilized seeds were soaked in five concentrations $(20,40,60,80$ and $100 \mathrm{ppm})$ of each nanoparticles (silicone and graphite) in addition to soaking in distilled water as the control. Seeds were soaked for $24 \mathrm{hr}$ at $\pm 2^{\circ} \mathrm{C}$ under dark conditions. Forty soaked seeds of each treatment were sown in 10 $\mathrm{cm}$ width Petri dishes top of two moistened layers of Whatman No. 1 filter paper and incubated at $25 \pm 2^{\circ} \mathrm{C}$ with $16 \mathrm{hr}$ illumination in four replicates. Germination data were documented every day for 9 days; seed with $2 \mathrm{~mm}$ radicle protrusion was considered as germinated. Radicle and plumule lengths as well as fresh and dry weights ware measured at seventh day.

\section{Germination parameters}

Germination percentage $(G)$ was computed following the ISTA (2011).

$\mathrm{G}(\%)=($ germinated seeds no/ total number of seeds) $\times 100$

Mean germination time (MGT) was calculated based on Matthews and Khajeh-Hosseini (2007).

$\mathrm{MGT}=\Sigma \mathrm{F} \times \mathrm{X} / \Sigma \mathrm{F}$

Where $\mathrm{F}$ is the number of seeds newly germinated at the time of $\mathrm{X}$, and $\mathrm{X}$ is the number of days from sowing. Seedling vigors were calculated based on Vashisth and Nagarajan (2010)

Vigor index I VI (I) = Germination $\% \times$ Seedling length $(\mathrm{cm})$ 
Vigor index II VI (II) $=$ Germination $\% \times$ Seedling weight $(\mathrm{g})$

Evaluations of Mean Daily Germination (MDG), Pick Value (PV) and Germination Value $(\mathrm{GV})$ were calculated by the following equations:

$\mathrm{MDG}=$ Germination $\%$ / Total experiment days.

$\mathrm{PV}=$ Maximum germinated seed number at one day /day number.

$\mathrm{GV}=\mathrm{PV} \times \mathrm{MDG}$

Mean Daily Germination (MDG), Pick Value (PV) and Germination Value (GV) were documented by Hartmann et al. (1990).

\section{Field experiment}

Two field experiments were performed through the two different seasons of 2013-2014 and 20142015 at El-Khashaa area, El-Hamoul, Kafr ElSheik Governorate to calculate the response of Pimpinella anisum L. for silica and graphite nanoparticles on yield characteristics, chemical composition, oil productivity and characteristics of root anatomy.

\section{Plant material and procedure}

The second part of primed seeds treated by nanoparticles were sown in the field on November $27^{\text {th }}$ in $1^{\text {st }}$ season and November $25^{\text {th }}$ in $2^{\text {nd }}$ one on rows at $60 \mathrm{~cm}$ apart in hills and $30 \mathrm{~cm}$ in between. Plot area was $4 \mathrm{~m}^{2}$ for each replicate contained 18 plant. After the complete germination, the seedlings were thinned to 2 plants per hill 30 days later of emergence.The experimental soil was analyzed and illustrated in Table 1

TABLE (a). Some physical and chemical soil properties of the experimental site as mean values of the two growth seasons

\begin{tabular}{|c|c|c|c|c|c|c|c|c|}
\hline $\begin{array}{c}\text { Organic } \\
\text { matter \% }\end{array}$ & Total N ppm & Total p ppm & $\begin{array}{c}\text { Total k } \\
\text { ppm }\end{array}$ & $\begin{array}{c}\text { Sand } \\
(\%)\end{array}$ & $\begin{array}{l}\text { Silt } \\
(\%)\end{array}$ & $\begin{array}{c}\text { Clay } \\
(\%)\end{array}$ & $\begin{array}{l}\text { Texture } \\
\text { class }\end{array}$ & pH. \\
\hline 0.94 & 32.70 & 22.50 & 780 & 10.78 & 19.85 & 69.37 & Clayey & 7.7 \\
\hline $\mathbf{E C}_{\mathrm{e}}$ & \multicolumn{4}{|c|}{ Inions concentration meq/L } & \multicolumn{4}{|c|}{ Cations concentration meq/L } \\
\hline$\left(\mathrm{dS} \mathrm{m}{ }^{-1}\right)$ & $\mathrm{CO}_{3}^{--}$ & $\mathrm{HCO}_{3}^{-}$ & $\mathrm{Cl}^{-}$ & $\mathrm{SO}_{4}^{--}$ & $\mathbf{C a}^{++}$ & $\mathbf{M g}^{++}$ & $\mathbf{N a}^{+}$ & $\mathrm{Caco}_{3} \%$ \\
\hline 5.6 & --- & 2.8 & 104 & 79 & 55 & 61 & 94 & 2.5 \\
\hline
\end{tabular}

TABLE 1. Effect of graphite and silica nanoparticles on GP \%, MGT (day), seedling length (cm), Seedling weight (g), VI I (cm), VI II (g), MDG, PV and GV of Pimpinella anisum L. seeds

\begin{tabular}{|l|c|c|c|c|c|c|c|c|c|}
\hline Traits & GP \% & (day) & Seedling & $\begin{array}{c}\text { Seedling } \\
\text { weight }\end{array}$ & VI I (cm) & $\begin{array}{c}\text { VI II } \\
\text { (g) }\end{array}$ & MDG & PV & GV \\
Treatments & & & & & & & & & \\
\hline Control & $80.0 \mathrm{~d}$ & $4.87 \mathrm{~g}$ & $5.461 \mathrm{abc}$ & $0.040 \mathrm{~b}$ & $436.88 \mathrm{ab}$ & $2.88 \mathrm{~d}$ & $8.00 \mathrm{~d}$ & $2.16 \mathrm{~b}$ & $17.280 \mathrm{c}$ \\
\hline GNps $20 \mathrm{ppm}$ & $72.5 \mathrm{~g}$ & $6.31 \mathrm{~b}$ & $5.419 \mathrm{abc}$ & $0.044 \mathrm{~b}$ & $392.85 \mathrm{ab}$ & $3.19 \mathrm{c}$ & $7.25 \mathrm{~g}$ & $1.30 \mathrm{i}$ & $9.425 \mathrm{i}$ \\
\hline GNps $40 \mathrm{ppm}$ & $67.5 \mathrm{~h}$ & $6.11 \mathrm{c}$ & $4.530 \mathrm{bc}$ & $0.031 \mathrm{c}$ & $305.75 \mathrm{~b}$ & $2.09 \mathrm{i}$ & $6.75 \mathrm{~h}$ & $1.42 \mathrm{~g}$ & $9.585 \mathrm{~h}$ \\
\hline GNps $60 \mathrm{ppm}$ & $75.0 \mathrm{f}$ & $6.40 \mathrm{~b}$ & $5.673 \mathrm{abc}$ & $0.043 \mathrm{~b}$ & $425.45 \mathrm{ab}$ & $3.22 \mathrm{~b}$ & $7.50 \mathrm{f}$ & $1.57 \mathrm{f}$ & $11.775 \mathrm{~g}$ \\
\hline GNps $80 \mathrm{ppm}$ & $85.0 \mathrm{c}$ & $5.47 \mathrm{e}$ & $3.768 \mathrm{c}$ & $0.030 \mathrm{c}$ & $320.25 \mathrm{~b}$ & $2.55 \mathrm{e}$ & $8.50 \mathrm{c}$ & $2.00 \mathrm{~d}$ & $17.00 \mathrm{~d}$ \\
\hline GNps $100 \mathrm{ppm}$ & $60.0 \mathrm{j}$ & $5.75 \mathrm{~d}$ & $6.181 \mathrm{ab}$ & $0.042 \mathrm{~b}$ & $370.84 \mathrm{~b}$ & $2.52 \mathrm{f}$ & $6.00 \mathrm{j}$ & $2.20 \mathrm{a}$ & $13.200 \mathrm{e}$ \\
\hline Si Nps $20 \mathrm{ppm}$ & $97.5 \mathrm{a}$ & $5.77 \mathrm{~d}$ & $5.652 \mathrm{abc}$ & $0.040 \mathrm{~b}$ & $551.02 \mathrm{a}$ & $3.90 \mathrm{a}$ & $9.75 \mathrm{a}$ & $2.20 \mathrm{a}$ & $21.450 \mathrm{a}$ \\
\hline Si Nps $40 \mathrm{ppm}$ & $50.0 \mathrm{k}$ & $5.25 \mathrm{f}$ & $6.795 \mathrm{a}$ & $0.050 \mathrm{a}$ & $339.72 \mathrm{~b}$ & $2.50 \mathrm{~g}$ & $5.00 \mathrm{k}$ & $1.40 \mathrm{~h}$ & $7.000 \mathrm{k}$ \\
\hline Si Nps $60 \mathrm{ppm}$ & $62.5 \mathrm{i}$ & $5.36 \mathrm{ef}$ & $5.420 \mathrm{abc}$ & $0.033 \mathrm{c}$ & $338.66 \mathrm{~b}$ & $2.06 \mathrm{j}$ & $6.25 \mathrm{i}$ & $1.16 \mathrm{j}$ & $7.250 \mathrm{j}$ \\
\hline Si Nps $80 \mathrm{ppm}$ & $77.5 \mathrm{e}$ & $6.67 \mathrm{a}$ & $5.207 \mathrm{abc}$ & $0.030 \mathrm{c}$ & $403.54 \mathrm{ab}$ & $2.32 \mathrm{~h}$ & $7.75 \mathrm{e}$ & $1.66 \mathrm{e}$ & 12.865 \\
\hline Si Nps $100 \mathrm{ppm}$ & $95.0 \mathrm{~b}$ & $5.73 \mathrm{~d}$ & $4.255 \mathrm{bc}$ & $0.022 \mathrm{~d}$ & $404.17 \mathrm{ab}$ & $2.09 \mathrm{i}$ & $9.50 \mathrm{~b}$ & $2.14 \mathrm{c}$ & $20.330 \mathrm{~b}$ \\
\hline
\end{tabular}


The recommended chemical fertilizer doses were added according to the Ministry of Agriculture as follows (300, 150 and $\left.50 \mathrm{~kg} \mathrm{fed}^{-1}\right)$ for ammonium nitrate $(33.5 \% \mathrm{~N})$, calcium superphosphate $(15.5$ $\left.\% \mathrm{P}_{2} \mathrm{O}_{5}\right)$ and potassium sulphate $\left(48 \% \mathrm{~K}_{2} \mathrm{O}\right)$, respectively. After thinning, plants were sprayed twice with the same nanoparticles levels used in germination test on January $23^{\text {rd }}$ and $21^{\text {th }}$ in the first and second season, respectively and before flowering stage on February $26^{\text {th }}$ and $19^{\text {th }}$ in both seasons, respectively. The following parameters were documented at the end of growth seasons when plants were harvested in the ripe dry fruits stage:

\section{Yield characteristics}

1. Number of umbels per plant.

2. Seed index (weight of 1000 seeds).

3. Seeds yield g/plant and/fed.

\section{Biochemical characteristics}

\section{Essential oil productivity and components}

Essential oil percentage was determined in the ripe dried fruits according to British Pharmacopoeia (1963). Gas chromatographic analysis was determined for essential oil in nine samples only for anise plant especially highly percentage oil samples which were obtained from treated plants with $20,60,80$ and100 ppm silica and graphite nanoparticles in addition to the control. GC/mass analysis of essential oil of each treatment was achieved with the specification of the apparatus used according to Robert (1995). Chlorophyll a, b and carotenoids were determined in fresh samples at the flowering stage according to the technique cleared by (Wettstein, 1957).

\section{Characteristics of root anatomy}

Roots samples of Pimpinella anisum L. were gathered from the mature plants during February 2015. The samples were taken from approximately the beginning of lowest half of the plant root and

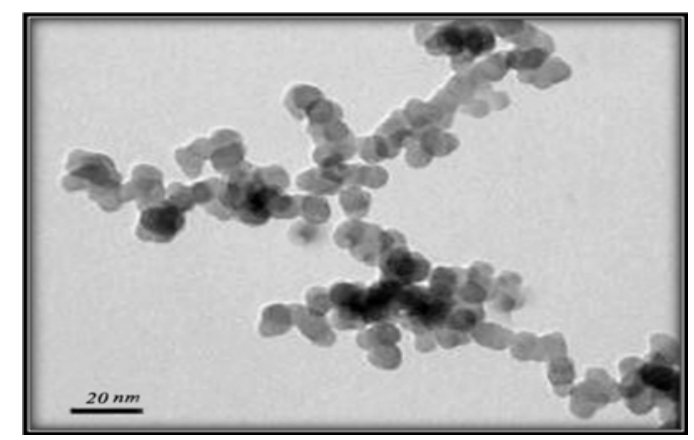

Silicon nanosized then fixed in formalin-acetic acid alcohol (FAA) using $70 \%$ ethanol. The samples were gradually dehydrated in a tert-butyl alcohol (TBA) series (Johansen, 1940) and embedded in paraffin wax (m.p. $56^{\circ} \mathrm{C}$ ). Sections were cut on a rotary microtome at a thinness of 8-10 $\mu \mathrm{m}$. Paraffin was removed with xylol, afterthat slides were stained with safranin FCF methanol and fast green, then mounted in Canada balsam (Johansen, 1940). The best sections were selected and examined then photographed by the light microscope.

\section{Nanomaterials type}

\section{Silica nanoparticles (SiNPs)}

SiNPs; $18 \mathrm{~nm}$ in average diameters, were prepared from rice husk by Dr. Magdy F. ElSamahy, Plant Protection Research Institute, Agriculture Research Center, Egypt, in the spherical form ( $98 \%$ purity).The SiNPs size was examined by transmission electron microscopy (TEM). It was found that the obtained SiNPs size ranged from 10 to $12 \mathrm{~nm}$ (Fig. 1). Using the BrunauerEmmett-Teller (BET) method (Brunauer, 1945), the result showed that the highest specific surface of the sample was about $320 \mathrm{~m}^{2} \mathrm{~g}^{-1}$. The obtained results in the mentioned method were proved that the rice husk from agricultural wastes can be used for the production of silica nanoparticles.

Graphite nanoparticles were purchased from NanoTech Egypt Co., Dreamland, Wahat Road, $6^{\text {th }}$ October, Egypt. The properties of graphite nanoparticles were purity: 99.9\% (metal base), range: $400 \mathrm{~nm}-1.2 \mathrm{um}, \mathrm{pH}=6-7$, fixed Carbon: $99 \%$, ash: $<0.5 \%$, impurities: (quartz + mica) $<$ $0.1 \%, \mathrm{H}_{2} \mathrm{O} \sim 0.2 \%$, morphology: flaky, color: black and the surface area: $6-8 \mathrm{~m}^{2} / \mathrm{g}$ (Fig. 1).

Concerning statistical analysis, the experimental layout was a complete randomized blocks design with three replicates. The main values of treatments were compared by Duncan's Multiple Range Test according to Snedecor and Cochran (1980) using MSTATIC computer program.

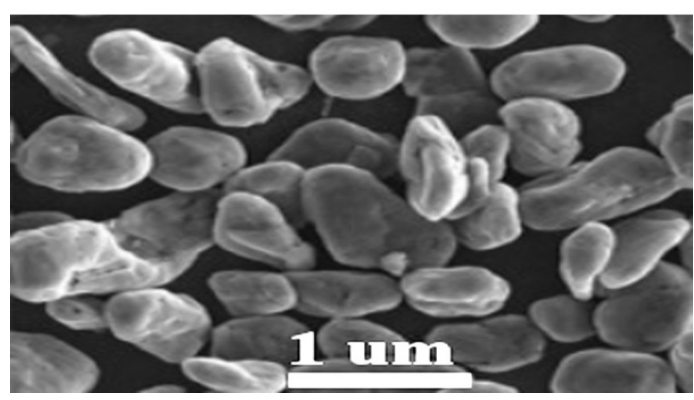

graphite nanosized

Fig.1. Images of $\mathrm{SiO} 2$ nanosized and graphite nanosized by Transmission Electron Microscope (TEM) 


\section{$\underline{\text { Results and Discussion }}$}

\section{Germination parameters}

Results in Table 2 showed significant positive or negative effects of graphite and silica nanoparticles on all germination parameters of anise seeds. The highest significant $\mathrm{G} \%$, vigor indices, MDG, PV and GV of seeds obtained from 20 ppm silica nanoparticles compared with the control. Moreover, the highest significant length and weight of seedling were recorded from $40 \mathrm{ppm}$ silica nanoparticles. Exposing the seeds to $80 \mathrm{ppm}$ silica nanoparticles led to increasing MGT. These findings could state that less and moderate concentration of silica nanoparticles could penetrate intact cell walls and transport different loads into plant cell organelles. Thus, NPs are able to penetrate plant cell walls and it is probable that the same process may be in place during seed germination (Lin et al., 2009) and might help the water absorption by the seeds (Zheng et al., 2005). Moreover, silica nanoparticles enhancement of the performance of chitinase and phytoalexin enzymes which help plants to prevent the contagion of microbial diseases (Luan et al., 2006). Similarly (Zhang et al., 2015, Agrawal \& Rathore, 2014 and Clement et al., 2013) showed the affirmative morphological effects of nanoparticles including better germination percentage and rate, length of root and shoot and their ratio, and vegetative biomass.

TABLE 2. Effect of graphite and silica nanoparticles on Number of umbels /plant, seeds yield/plant and /fed and1000 seeds weight of Pimpinella anisumL plants in the two seasons 2014 and 2015

\begin{tabular}{|c|c|c|c|c|c|c|c|c|}
\hline \multirow[b]{2}{*}{ Treatments } & \multicolumn{2}{|c|}{ Umbels no/plant } & \multicolumn{2}{|c|}{$\begin{array}{c}\text { Seeds yield/plant } \\
\text { (g) }\end{array}$} & \multicolumn{2}{|c|}{$\begin{array}{c}\text { Seeds yield/fed } \\
\text { (kg) }\end{array}$} & \multicolumn{2}{|c|}{$\begin{array}{c}1000 \text { seeds weight } \\
(\mathrm{g})\end{array}$} \\
\hline & $1^{\text {st }}$ seasons & $\begin{array}{c}2^{\text {nd }} \\
\text { seasons }\end{array}$ & $\begin{array}{c}1^{\text {st }} \\
\text { seasons }\end{array}$ & $\begin{array}{c}2^{\text {nd }} \\
\text { seasons }\end{array}$ & $1^{\text {st }}$ seasons & $2^{\text {nd }}$ seasons & $1^{\text {st }}$ seasons & $2^{\text {nd }}$ seasons \\
\hline Control & $60.00 \mathrm{c}$ & $52.33 \mathrm{bc}$ & $5.19 \mathrm{c}$ & $6.56 \mathrm{bc}$ & $232.74 \mathrm{c}$ & $293.81 \mathrm{~b}-\mathrm{e}$ & $4.15 \mathrm{bcd}$ & $3.90 \mathrm{abc}$ \\
\hline GNps 20 ppm & $67.00 \mathrm{~b}$ & $61.00 \mathrm{~b}$ & $6.16 \mathrm{~b}$ & $7.38 \mathrm{~b}$ & $276.04 \mathrm{~b}$ & $330.40 \mathrm{bc}$ & $3.99 \mathrm{~d}$ & $3.60 \mathrm{~cd}$ \\
\hline GNps 40 ppm & $47.00 \mathrm{e}$ & $43.66 \mathrm{c}$ & $4.73 \mathrm{c}$ & $6.39 \mathrm{bc}$ & $211.83 \mathrm{~cd}$ & 286.34 cde & $3.87 \mathrm{~d}$ & $3.79 \mathrm{bcd}$ \\
\hline GNps 60 ppm & $35.33 \mathrm{~h}$ & $28.33 \mathrm{~d}$ & $3.53 \mathrm{~d}$ & $3.53 \mathrm{e}$ & $158.07 \mathrm{e}$ & $158.92 \mathrm{~g}$ & $4.08 \mathrm{~cd}$ & $3.93 \mathrm{abc}$ \\
\hline GNps 80 ppm & $38.66 \mathrm{gh}$ & $45.00 \mathrm{c}$ & $2.93 \mathrm{e}$ & $6.53 \mathrm{bc}$ & $131.18 \mathrm{f}$ & $292.32 \mathrm{~b}-\mathrm{e}$ & $3.37 \mathrm{e}$ & $3.43 \mathrm{~d}$ \\
\hline GNps 100 ppm & $53.33 \mathrm{~d}$ & $44.66 \mathrm{c}$ & $4.53 \mathrm{c}$ & $5.78 \mathrm{~cd}$ & $202.86 \mathrm{~d}$ & 258.72 ef & $4.64 \mathrm{a}$ & $4.02 \mathrm{abc}$ \\
\hline Si Nps 20 ppm & $64.00 \mathrm{bc}$ & $52.66 \mathrm{bc}$ & $6.49 \mathrm{~b}$ & $7.14 \mathrm{bc}$ & $290.97 \mathrm{~b}$ & $319.94 \mathrm{bcd}$ & $4.13 \mathrm{bcd}$ & $4.35 \mathrm{a}$ \\
\hline Si Nps 40 ppm & $41.00 \mathrm{fg}$ & $41.00 \mathrm{c}$ & $3.76 \mathrm{~d}$ & $5.06 \mathrm{~d}$ & $168.52 \mathrm{e}$ & $226.61 \mathrm{f}$ & $4.49 \mathrm{ab}$ & $4.32 \mathrm{a}$ \\
\hline Si Nps 60 ppm & $45.33 \mathrm{ef}$ & $50.00 \mathrm{bc}$ & $4.59 \mathrm{c}$ & $6.34 \mathrm{bc}$ & $205.87 \mathrm{~cd}$ & $284.10 \mathrm{de}$ & $4.39 \mathrm{abc}$ & $4.14 \mathrm{ab}$ \\
\hline Si Nps 80 ppm & $90.00 \mathrm{a}$ & $80.00 \mathrm{a}$ & $8.56 \mathrm{a}$ & $9.34 \mathrm{a}$ & $383.56 \mathrm{a}$ & $418.50 \mathrm{a}$ & $4.10 \mathrm{~cd}$ & $3.90 \mathrm{abc}$ \\
\hline Si Nps 100 ppm & $59.00 \mathrm{c}$ & $61.00 \mathrm{~b}$ & $4.86 \mathrm{c}$ & $7.43 \mathrm{~b}$ & $217.80 \mathrm{~cd}$ & $332.64 \mathrm{~b}$ & $4.39 \mathrm{abc}$ & $3.96 \mathrm{abc}$ \\
\hline
\end{tabular}

Means, in each column, followed by similar letter are not significantly different at the $5 \%$ probability level - using Duncan 's Multiple Range Test.

Phytotoxicity and stimulatory effects of graphite and silica nanoparticles

Allgraphite and $\mathrm{SiO}_{2}$ nanoparticles concentration reduced germination $\%$ up to $37.5 \%$ at $40 \mathrm{ppm} \mathrm{SiO}_{2}$ NPs except for 80ppm graphite NPs, 20 and100ppm $\mathrm{SiO}_{2}$ NPs compared to the control (Fig. 2). In addition, all graphite and $\mathrm{SiO}_{2}$ nanoparticles treatments had a negative effect on MGT, 80ppm silica nanoparticles greatly decreased MGT up to $26.99 \%$ compared to the control seeds. It seems that seedling length and weight were not significantly affected by nanoparticles concentration. Application of $80 \mathrm{ppm}$ graphite NPs and 100ppm $\mathrm{SiO}_{2}$ NPs extremely decreased seedling elongation and seedling weight up to 31 and $22.08 \%$, respectively compared with unexposed seeds but 40ppm $\mathrm{SiO}_{2}$ NPs did not demonstrate such reduction in seedling length and weight. Nonetheless, this concentration (40ppm $\mathrm{SiO}_{2}$ NPs) led to enhancing length and weight of seedling by 19.63 and $20 \%$, respectively compared to the non-exposure treatment. The reason for this can be attributed to increasing the concentration of nanoparticles may induced aggregation of particles and resulted in clogging of root pores that interrupted water uptake by seeds (Feizi et al., 2013). In addition, application of nanoparticles decreased vigor indeces, MDG, 
$\mathrm{PV}$, and GV except application of $20 \mathrm{ppm} \mathrm{SiO}_{2}$ NPs greatly increased up to $20.71,26.15,17.95$, 1.82 and $19.44 \%$, respectively compared to the control. The reason for this decrease may be that nanoparticle could stimulate the process of seed germination like water and oxygen uptake resulting in improving seed germination percentage but in later growth stages, seedling might respond as different (Feizi et al. 2013). Also, it is possible that the seeds enhanced by nanoparticle and then cultivated in soil in the field. In this condition it is possible physicochemical properties of soil modify adverse effects on plant growth and weights. Moreover, the key reason for this growth increasing could have been the photo-sterilization and photogeneration of active oxygen like, superoxide and hydroxide anions by $\mathrm{SiO}_{2} \mathrm{NPs}$ that enhanced seed stress resistance and encouraged capsule penetration for intakes of water and oxygen needed for quick germination (Khot et al., 2012).

\section{Yield characteristics}

Graphite and silica nanoparticles (Table 3) significantly diminished thenumberofumbels plant ${ }^{-1}$ and seeds yield plant ${ }^{-1}$ except for 20ppm GNps and 20, 80 and100 ppm $\mathrm{SiO}_{2}$ nanoparticles. In this regard, high concentration $80 \mathrm{ppm}$ of $\mathrm{SiO}_{2}$ nanoparticles recorded the highest number of umbels plant ${ }^{-1}$ and seeds yield plant ${ }^{-1}$ and fed. Otherwise, useful effects of most $\mathrm{SiO}_{2}$ nanoparticles concentration on 1000 seeds weight. These results may be because of the increasing amounts of pigments which led to increasing yield (Yang and Hong, 2006). These results respectively agree with those obtained by Abdul Qados and Moftah (2015). The stimulatory impacts on umbels number and seeds yield plant ${ }^{-1}$ and $/$ fed. $\mathrm{SiO}_{2}$ nanoparticles $80 \mathrm{ppm}$ increased the number of umbels /plant by 50 and $52.88 \%$, seeds yield/plant by 64.93 and $42.38 \%$ and seeds yield/fed by 64.8 and $42.44 \%$ in both seasons, respectively (Fig. 3). An increase in germination indices by using $\mathrm{SiO} 2 \mathrm{NPs}$ could be effective for the growth and yield of crops. However, the interaction mechanism between nanosilica and plants which establishes that nano $\mathrm{SiO}_{2}$ could be used as a fertilizer for the crop improvement (Siddiqui and Al-Whaibi, 2014).

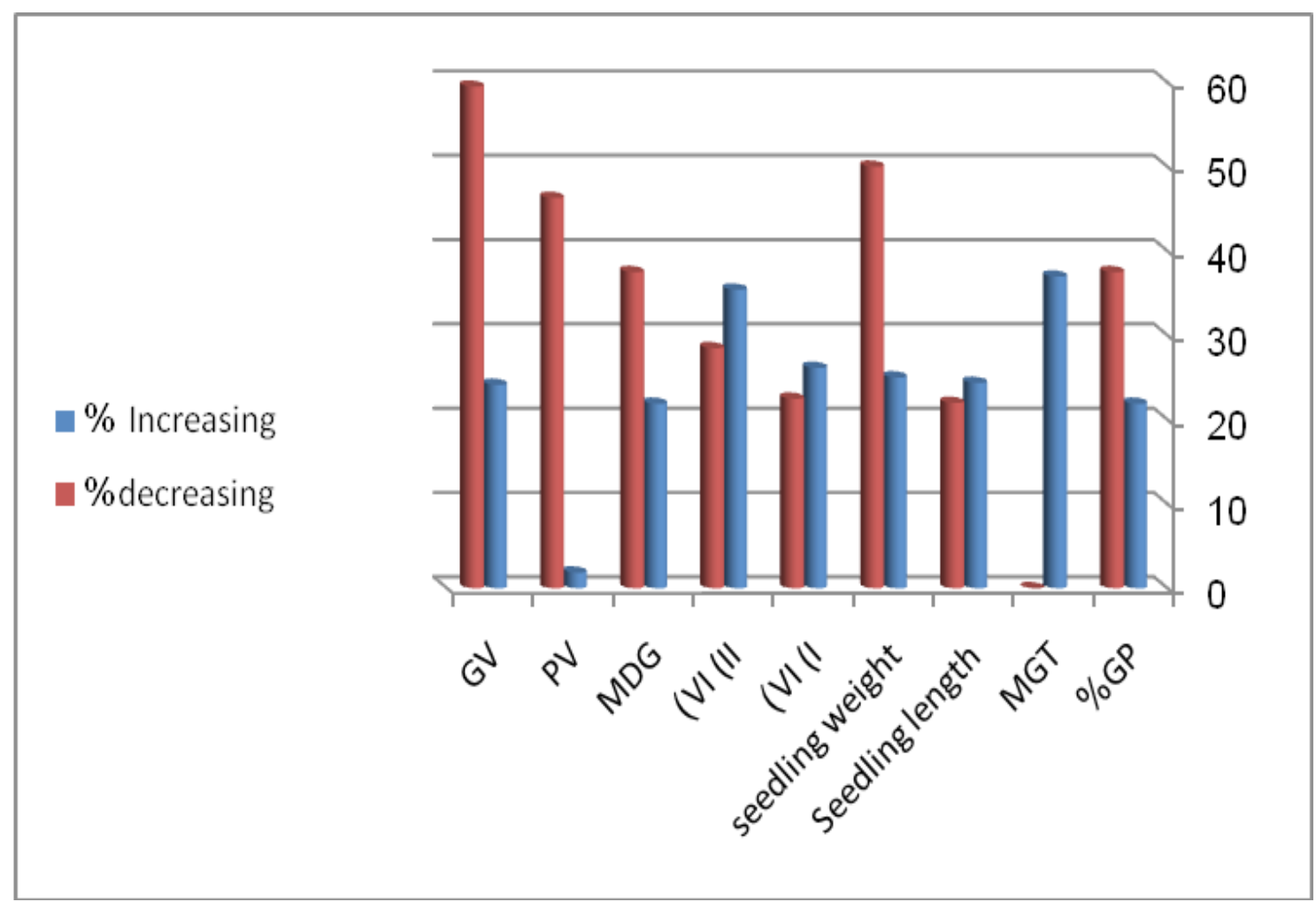

Fig.2. Impact of graphite and silicananoparticles on increasing and decreasing\% of all germination anise traits 
TABLE 3. Effect of graphite and silica nanoparticles on chlorophyll a, chlorophyll b, carotenoidsandVolatile oil\% of pimpinella anisumL plants in the two seasons 2014 and 2015

\begin{tabular}{|c|c|c|c|c|c|c|c|c|}
\hline \multirow{2}{*}{$\begin{array}{c}\text { Traits } \\
\text { Treatments }\end{array}$} & \multicolumn{2}{|c|}{ Chlorophyll a } & \multicolumn{2}{|c|}{ Chlorophyll b } & \multicolumn{2}{|c|}{ Carotenoids } & \multicolumn{2}{|c|}{ Volatile oil\% } \\
\hline & $\begin{array}{c}1^{\text {st }} \\
\text { seasons }\end{array}$ & $\begin{array}{c}2^{\text {nd }} \\
\text { seasons }\end{array}$ & $\begin{array}{c}1^{\text {st }} \\
\text { seasons }\end{array}$ & $\begin{array}{c}2^{\text {nd }} \\
\text { seasons }\end{array}$ & $\begin{array}{c}1^{\text {st }} \\
\text { seasons }\end{array}$ & $\begin{array}{c}2^{\text {nd }} \\
\text { seasons }\end{array}$ & $\begin{array}{c}1^{\text {st }} \\
\text { seasons }\end{array}$ & $\begin{array}{c}2^{\text {nd }} \\
\text { seasons }\end{array}$ \\
\hline Control & $1.53 \mathrm{bc}$ & $1.42 \mathrm{c}$ & $1.38 \mathrm{~b}$ & $1.72 \mathrm{~cd}$ & $7.08 \mathrm{bc}$ & $5.64 \mathrm{c}$ & $1.39 \mathrm{ab}$ & $1.19 \mathrm{ab}$ \\
\hline GNps 20 ppm & $1.71 \mathrm{~b}$ & $1.55 \mathrm{bc}$ & $1.89 \mathrm{a}$ & $1.85 \mathrm{c}$ & $8.10 \mathrm{ab}$ & $6.71 \mathrm{~b}$ & $1.20 \mathrm{c}$ & $1.09 \mathrm{~b}$ \\
\hline GNps 40 ppm & $1.33 \mathrm{~d}$ & $1.40 \mathrm{c}$ & $0.86 \mathrm{c}$ & $1.57 \mathrm{~d}$ & $6.18 \mathrm{c}$ & $5.54 \mathrm{c}$ & $0.95 \mathrm{~d}$ & $0.79 \mathrm{~cd}$ \\
\hline GNps 60 ppm & $1.66 \mathrm{~b}$ & $1.44 \mathrm{c}$ & $1.61 \mathrm{ab}$ & $1.69 \mathrm{~cd}$ & $8.45 \mathrm{ab}$ & $5.88 \mathrm{c}$ & $0.64 \mathrm{e}$ & $0.46 \mathrm{e}$ \\
\hline GNps 80 ppm & $1.23 \mathrm{~d}$ & $1.36 \mathrm{c}$ & $0.63 \mathrm{c}$ & $1.31 \mathrm{e}$ & $4.16 \mathrm{~d}$ & $4.96 \mathrm{~d}$ & $1.45 \mathrm{a}$ & $1.32 \mathrm{a}$ \\
\hline GNps 100 ppm & $1.39 \mathrm{~cd}$ & $1.48 \mathrm{bc}$ & $1.44 \mathrm{ab}$ & $1.68 \mathrm{~cd}$ & $8.24 \mathrm{ab}$ & $6.04 \mathrm{c}$ & $1.41 \mathrm{ab}$ & $1.22 \mathrm{ab}$ \\
\hline Si Nps 20 ppm & $1.92 \mathrm{a}$ & $1.73 \mathrm{ab}$ & $1.64 \mathrm{ab}$ & $2.32 \mathrm{a}$ & $8.28 \mathrm{ab}$ & $7.00 \mathrm{~b}$ & $1.35 \mathrm{ab}$ & $1.20 \mathrm{ab}$ \\
\hline Si Nps 40 ppm & $1.65 \mathrm{~b}$ & $1.65 \mathrm{abc}$ & $1.57 \mathrm{ab}$ & $1.81 \mathrm{c}$ & $8.05 \mathrm{ab}$ & $6.23 \mathrm{c}$ & $0.66 \mathrm{e}$ & $0.50 \mathrm{e}$ \\
\hline Si Nps 60 ppm & $1.93 \mathrm{a}$ & $1.77 \mathrm{a}$ & $1.79 \mathrm{ab}$ & $2.34 \mathrm{a}$ & $8.96 \mathrm{a}$ & $7.52 \mathrm{a}$ & $0.89 \mathrm{~d}$ & $0.69 \mathrm{~d}$ \\
\hline Si Nps 80 ppm & $1.56 \mathrm{bc}$ & $1.62 \mathrm{abc}$ & $1.43 \mathrm{ab}$ & $2.00 \mathrm{~b}$ & $7.52 \mathrm{abc}$ & $6.04 \mathrm{c}$ & $1.28 \mathrm{bc}$ & $1.18 \mathrm{ab}$ \\
\hline Si Nps 100 ppm & $1.60 \mathrm{bc}$ & $1.64 \mathrm{abc}$ & $1.48 \mathrm{ab}$ & $1.75 \mathrm{~cd}$ & $7.08 \mathrm{bc}$ & $6.02 \mathrm{c}$ & $1.02 \mathrm{~d}$ & $0.88 \mathrm{c}$ \\
\hline
\end{tabular}

's Multiple Range Test.

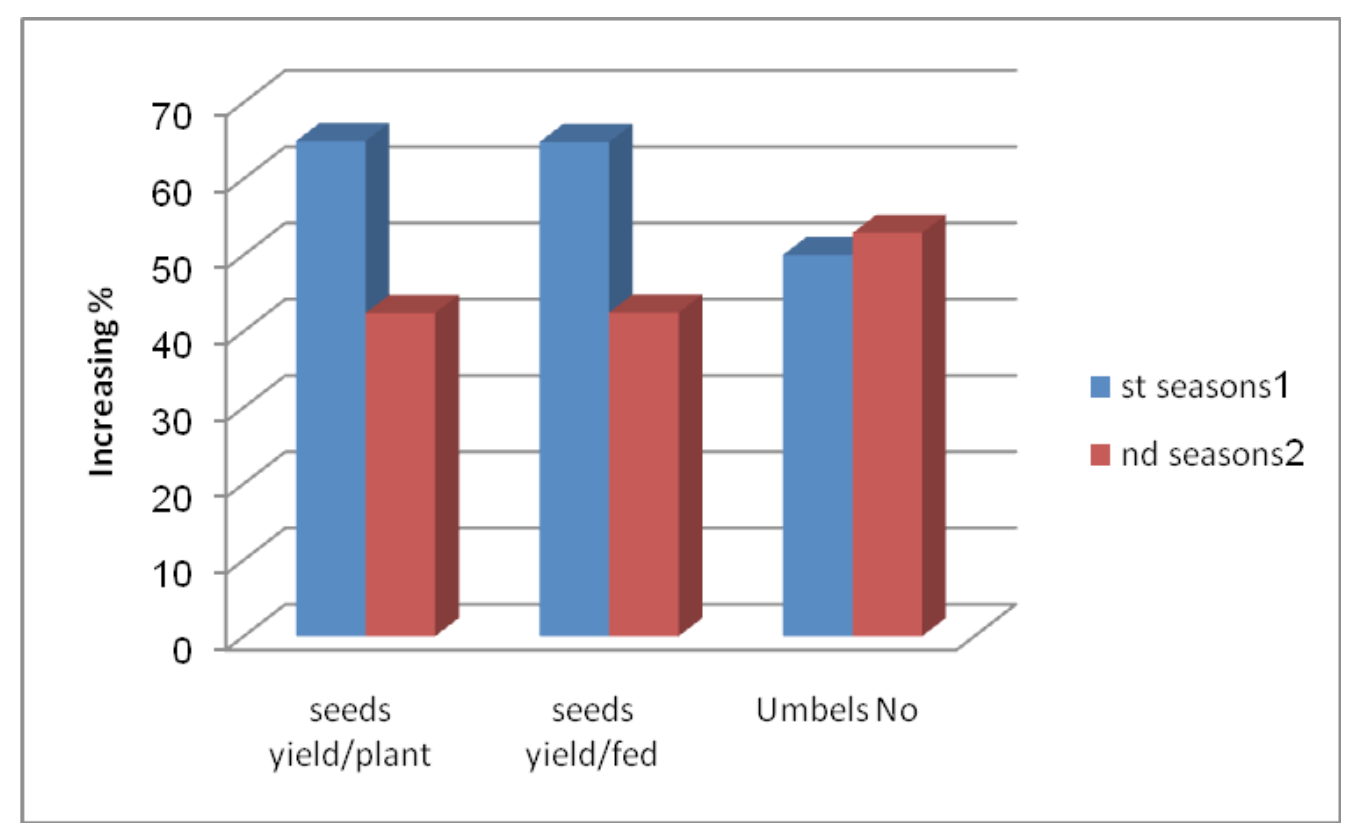

Fig. 3. Stimulatory impacts of $80 \mathrm{ppm}$ SiO2Nanoparticles on umbels number and seeds yield /plant and/fed as comparing with untreated 
Concerning the correlation between umbels number/plant and seed yield/plant, the relation can be shown in Fig. 4. There is a complete correlation $\mathrm{R} 2=1$ in the two seasons. Furthermore, increasing umbels number/plant led to enhanced seeds yield/plant and/fed in the two seasons; this clearly on 80 ppm $\mathrm{SiO}_{2}$ NPs. These finding agreed with those of Phu et al. (2017) and Morteza et al. (2013).

\section{Biochemical characteristics}

According to Table 4, the highest percentage of chlorophyll a, b and carotenoids resulted from using $60 \mathrm{ppm} \mathrm{SiO}_{2}$ nanoparticles and the lowest evaluation for this traits was achieved by soaking and spraying with $80 \mathrm{ppm}$ graphite NPs. Also, the same concentration of $80 \mathrm{ppm}$ graphite NPs recorded the highest volatile oil\% higher than $\mathrm{SiO}_{2}$ nanoparticles and the control treatment. While, the lowest volatile oil\% was achieved by 60ppm graphite NPs and 40ppm $\mathrm{SiO}_{2}$ nanoparticles. These results revealed that nano $\mathrm{SiO}_{2}$ could stabilize the integrality of chloroplast membrane and protect the chloroplasts from aging in contrast with the control. Therefore, with nano $\mathrm{SiO}_{2}$ treatment spraying, the content of chlorophyll a, b and carotenoids, was higher than the control. Moreover, spraying with $\mathrm{SiO}_{2}$ NPs increasing chlorophyll pigments and transmit of photosynthetic material from leaves to fruits at the flowering time, leaves are starting to age and the first synthetic indicator of that was changing the structure and function of the chloroplasts (Woolhouse, 1984). Yang and Hong (2006) revealed that photosynthesis improved by Tio 2 NPs may be due to stimulation of the photochemical reaction of the plant chloroplasts. These results are in agreement with those of Salama (2012), Sharma et al. (2012) and Razzaq et al.(2016).

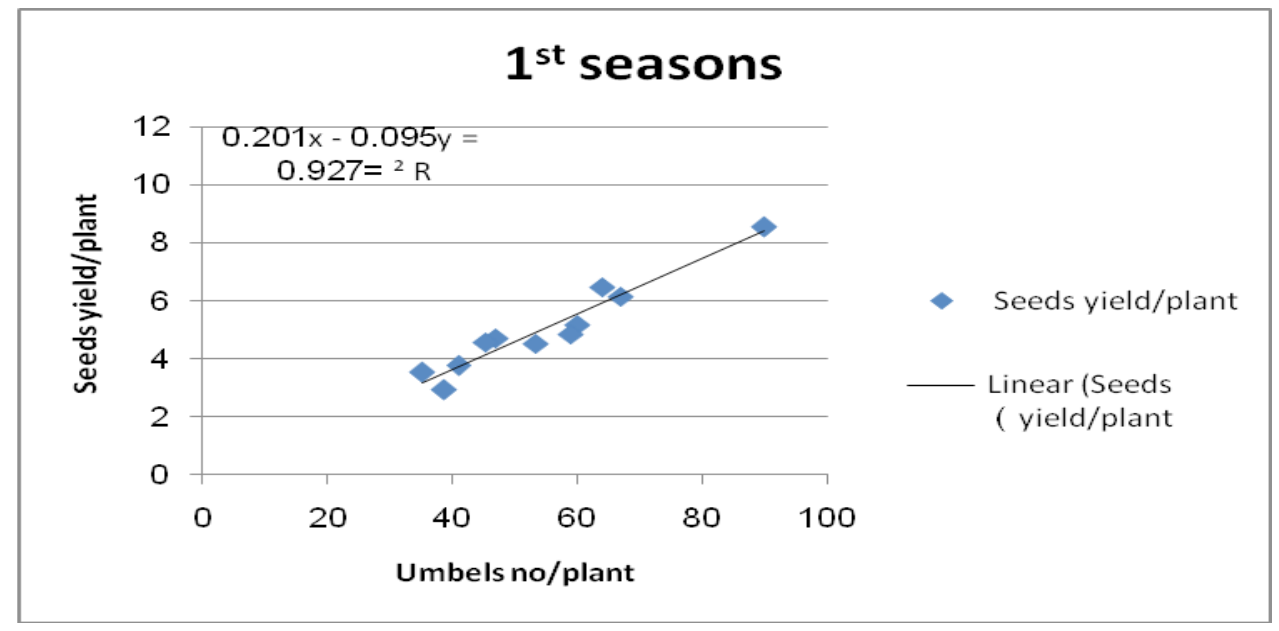

Fig.4. Correlation between umbels number/plant and seeds yield /plant as affected with Nano particles treatments

TABLE 4. Effect of graphite and silica nanoparticles on Oil components of pimpinella anisumL plants in the second seasons (2014 and 2015)

\begin{tabular}{|l|c|c|c|c|c|c|c|c|c|}
\hline \multicolumn{1}{|r|}{ Treatments } & control & $\begin{array}{c}\text { G Nps } \\
20 \mathrm{ppm}\end{array}$ & $\begin{array}{c}\text { G Nps } \\
40 \mathrm{ppm}\end{array}$ & G Nps & G Nps & Si Nps \\
Components & $100 \mathrm{ppm}$ & Si Nps & Si Nps & Si Nps \\
\hline p-cymene & 0.26 & 0.76 & 1.83 & 0.28 & 0.25 & 0.86 & 4.82 & 0.35 & 0.17 \\
\hline Linalool & 0.95 & 0.89 & 1.13 & 1.21 & 1.21 & 1.62 & 2.61 & 0.96 & 0.77 \\
\hline Methyl chavicol & 0.44 & 0.60 & 0.28 & 0.23 & 0.22 & 0.18 & 0.15 & 0.29 & 0.15 \\
\hline Trans-anethole & 95.86 & 93.61 & 92.41 & 95.73 & 95.33 & 94.28 & 87.49 & 96.28 & 94.59 \\
\hline Anise-aldehyde & 1.38 & 2.31 & 1.48 & 1.53 & 2.30 & 1.66 & 1.47 & 1.43 & 2.45 \\
\hline Unidentifiedcompound & 1.11 & 1.83 & 2.87 & 1.02 & 0.69 & 1.4 & 3.46 & 0.69 & 1.87 \\
\hline
\end{tabular}




\section{Essential oil constituents}

Main compounds and their relative percentage in the essential oil are shown in Table 5. Data revealed that five components were recognized as p-cymene, linalool, methyl chavicol, transanethole, anise aldehyde. Trans-anethole was found to be the first major compound and ranged from 96.28 to $87.49 \%$. Its maximum content was observed in the volatile oil with 80 ppmSiO$_{2}$ nanoparticle. While, the minimum content was recorded with $60 \mathrm{ppmSiO}_{2}$ nanoparticle. Anise-aldehyde was recorded as the second main compound identified ranged from2.31 to1.38 for 20 ppmgraphitenanoparticle and control, respectively. The change in the components quality occurred by using different nanoparticle treatments may be due to their effects on the metabolism and on this enzyme responsible for the components synthesis (Yousefzadeh and Sabaghnia., 2016).

\section{Anatomical characteristics of anise root}

It was reported that graphite and silica nanoparticles had a significant effect on root anatomy characteristics of Pimpinella anisum L. plant (Table 6 and Fig 5). A raise in the concentration of silica nanoparticles ( $80 \mathrm{ppm})$ has led to an improvement in root diameter, epidermis thickness and cortex thickness nevertheless, caused a decrease in vascular cylinder thickness compared with the control. In contrast, vascular cylinder thickness increased on treated plants with $80 \mathrm{ppm}$ graphite nanoparticles. These results may be attributed to the mechanisms by which silicon is absorbed into the plants and interacted with polyphenols in cell walls of xylem and affected lignin deposition and biosynthesis (Parry and Kelso, 1975). These results are in harmony with previous results reported by Elfeky et al. (2013) who proved that epidermis cells of untreated plants of Ocimumbasilicum were similar in shape and size, while the epidermal cells of the NPtreated leaves became larger in size, in addition, the thickness of mesophyll tissue was greater.

TABLE 5. Effect of graphite and silica nanoparticles on root diameter, epidermis thickness,cortex thicknessandvascular cylinder thickness of root anatomy of Pimpinella anisum Lplants in the second seasons (2015)

\begin{tabular}{|l|c|c|c|c|}
\hline \multicolumn{1}{|c|}{ Characteristics } & $\begin{array}{c}\text { Root } \\
\text { diameter }\end{array}$ & Epidermis thickness & Cortex thickness & $\begin{array}{c}\text { Vascular cylinder } \\
\text { thickness }\end{array}$ \\
\hline Control & $3875 \mathrm{c}$ & $20 \mathrm{~b}$ & $562.5 \mathrm{~b}$ & $2500 \mathrm{~b}$ \\
\hline $20 \mathrm{ppm}$ nanographite & $2412.3 \mathrm{~d}$ & $10 \mathrm{c}$ & $500 \mathrm{~b}$ & $1500 \mathrm{c}$ \\
\hline $80 \mathrm{ppm}$ nanographite & $4125 \mathrm{~b}$ & $20 \mathrm{~b}$ & $550 \mathrm{~b}$ & $3000 \mathrm{a}$ \\
\hline $80 \mathrm{ppm}$ nanosilica & $4625 \mathrm{a}$ & $25 \mathrm{a}$ & $762.5 \mathrm{a}$ & $1025 \mathrm{~d}$ \\
\hline
\end{tabular}

Means having the same letters in the column are not significantly different at 5\% levelaccording to Dunkan,s Multiple Range Test.

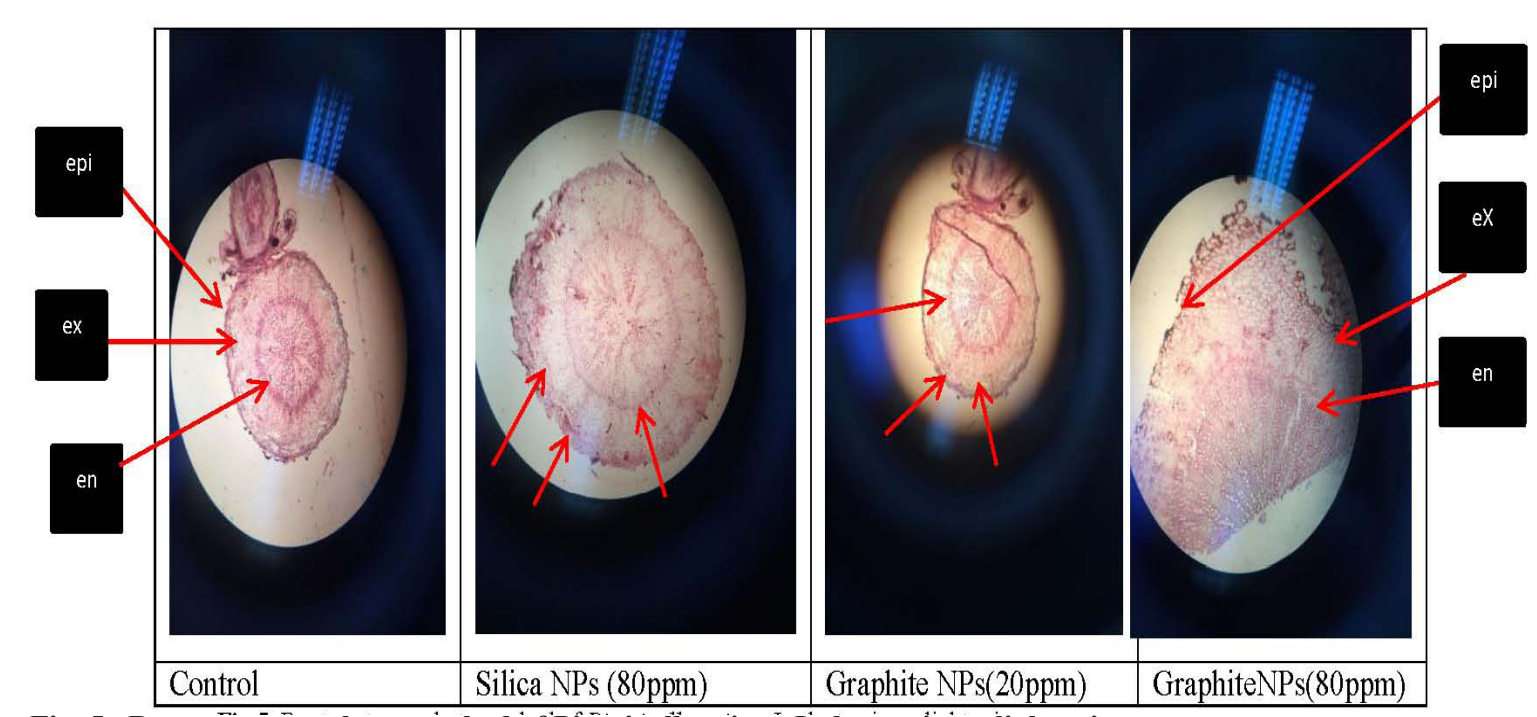

Fig. 5. Root anatomy photographed of PímpinellaanisumĹplant using a light microscope

Abbreviations: epi,epidermis; ex, exodermis; en, endodermis. 
Several studies have shown this result like Zuverza-Mena et al. (2016) and Keller et al. (2015); they found that Si deposition not only takes place in various parts of the plant such as epidermis of shoots but can also take place in the cell wall of root endodermis.

\section{Conclusion}

For improving seed germination can be soaked seeds in 20 to $40 \mathrm{ppm}$ silica nanoparticles NPs. For enhancing seeds yield/plant and /fed, umbels number/plant, the diameter, epidermis, and cortex thickness of root we can be soaked anise seeds and foliar application of 60 and $80 \mathrm{ppm}$ silica NPs for promoting biochemical characterization, oil components of the plant. Nevertheless, 80ppm graphite NPs enhanced volatile oil $\%$ and vascular cylinder thickness of root. In general,Applications of the nanoparticle can promote seed germination; improve yield productionand chemical characters of anise plants.

\section{Acknowledgement}

My respect, gratitude and sincere thanks are due to Dr. Magdy Farouk El-Samahy, associate professor of nanotechnology and plant protection, Field Crop Pests Research Department, Plant Protection Research Institute, Sakha Agricultural Research Station, Agricultural Research Center for preparing silica nanoparticles and providing graphite nanoparticles.

\section{References}

Abdel Latef, A.A. and Tran, L.P. (2016) Impacts of priming with silicon on the growth and tolerance of maize plants to alkaline stress. Frontiers in Plant Science, 7(243), 1-10.

Abdul Qados, A. M. S. and Moftah, A. E. (2015) Influence of silicon and nano-silicon on germination, growth and yield of faba bean (Viciafaba L.) under salt stress conditions. Amer. J. Exper. Agric., 5 (6), 509-524.

Agrawal, S. and Rathore, P. (2014) Nanotechnology pros and cons to agriculture: a review. Int. J. Curr. Microbiol. Appl. Sci., 3, 43-55.

Amin, A., Li,Y. and Finkelstein, R. (1999) Hedgehog activates the EGF receptor pathway during Drosophila head development. Development, 126 (12), 2623-2630.

British Parmacopoeia (1963) Determination of Volatile Oil in Drugs. The Pharmaceutical Press, London.
Brunauer, S. (1945) The Adsorption of Gases and Vapors, vol. 1, Princeton University Press, Princeton, NJ.

Canas, J.E., Long, M., Nations, S.,Vadan, R., Dai, L., Luo, M., Ambikapathi, R., Lee, E.H. andOlszyk, D.(2008) Effects of functionalized and non-functionalized single-walled carbon nanotubes on root elongation of select crop species. Environ. Toxicol. Chem., 27, 1922-1931.

Clement, L., Hurel, C. and Marmier, N. (2013) Toxicity of $\mathrm{TiO}_{2}$ nanoparticles to cladocerans, algae, rotifers and plants effects of size and crystalline structure. Chemosphere, 90, 1083-1090.

Elfeky, S.A., Mohammed, M.A., Khater, M.S., Osman,Y.A.H. and Elsherbini, E. (2013) Effect of magnetite Nano-Fertilizer on Growth and yield of Ocimum basilicum L. Int. J. of Ind. Med., 46 (3), 1286-1293.

Feizi, H., Kamali, M., Jafari, L. and Moghaddam, P.R.(2013) Phytotoxicity and stimulatory impacts of nanosized and bulk titanium dioxide on fennel (Foeniculumvulgare Mill).Chemosphere, 91, 506511

Guo, Z. (2000) Synthesis of the needle-like silica nanoparticles by biomineral method [J]. Chemical Journal of Chinese Universities, 21(6), 847-848.

Hartmann, H.T., Kester, D.E. and Davies, F.T. (1990) Plant Propagation: Principles and Practices. Prentice Hall, Englewood Cliffs, New Jersey. P:647.

Hu, Y. and Schmidhalter, U. (2005) Drought and salinity: A comparison of their effects on mineral nutrition of plants. J. Plant Nutrition Soil Science, 168, 541-549.ISTA. (2011) International rules for seed testing, Zurich: Switzerland.

Johansen, D.A. (1940) Plant Microtechnique. McGraw Hill Book Co. Inc., New York, London.

Keller, C., Rizwan, M., Davidian, J.-C., Pokrovsky, O.S., Bovet, N., Chaurand, P., Meunier, J.-D., (2015) Effect of silicon on wheat seedlings (Triticum turgidum L.) grown in hydroponics and exposed to 0 to $30 \mu \mathrm{M} \mathrm{Cu}$. Planta,241, 847-860.

Khodakovskaya, M. , Dervishi, E., Mahmood, M., Xu, Y., Li, Z., Watanabe, F. and Biris, A. S. (2009) Carbon nanotubes are able to penetrate plant seed coat and dramatically affect seed germination and plant growth.Am. Chem. Soc. 3 (10), 3221-3227.

Khodakovskaya, M.V, De Silva, K., Biris, A.S, Dervishi, E. and Villagarcia, H. (2012) Carbon nanotubes induce growth enhancement of tobacco cells. A.C.S. Nano, 6, 2128-2135 
Khot, L.R., Sankaran, S., Mari, J.,Maja, Ehsani, R. and Schuster, E.W. (2012)Applications of nanomaterials in agricultural production and crop protection: a review. Crop Protection, 35, 64-70.

Klaus, A., Beatovic, D., Niksic, M., Jelacic, S. and Petrovic, T. (2009) Antibacterial activity oils from Serbia against the Listeria monocytogenes. J. Agri. Sci., 54 (2), 95-104.

Lin, C., Fugetsu, B., Su, Y. and Watari, F. (2009) Studies on toxicity of multi-walled carbon nanotubes on Arabidopsis T87 suspension cells. J. Hazard Mater. 170, 578-583.

Luan, L. Q.,Nagasawa, N.,Tamada, M. and Nakanishi, T. M.(2006) Enhancement of plant growth activity of irradiated chitosan by molecular weight fractionation. Radioisotopes., 55(1), 21-27.

Matthews, S. and Khajeh-Hosseini, M. (2007) Length of the lag period of germination and metabolic repair explain vigor differences in seed lots of maize (Zea mays). Seed.Sci.Technol. 35, 200-212.

Morla., S , Ramachandra Rao, C. S. V. and Chakrapani, R. (2011) Factors Affecting Seed Germination and Seedling Growth of Tomato Plants cultured in Vitro Conditions. J. Chem. Bio. Phy. Sci., 1 (2), 328-334.

Morteza Elham, P. ,Moaveni,Farahani H. A. and Kiyani, M. (2013) Study of photosynthetic pigments changes of maize (Zea mays L) under nano Tio2 spraying at various growth stages. Springer Plus, 2, 247.

Nabizadeh, E., Habibi, H. and Hosainpour, M. (2012) The effect of fertilizers and biological nitrogen and planting density on yield quality and quantity Pimpinella anisum L. European Journal of Experimental Biology., 2,1326-1336.

Parry, D.W. and Kelso, M.(1975)The distribution of silicon deposits in the root, Molina caerulea L. Moench and Sorghum bicolorLMoench. Ann. Bot., 39, 9951001.

Pei, Z.F.,Ming, D.F., Liu, D., Wan, G.L.,Geng, X.X., Gong, H.J. and Zhou, W.J. (2010) Silicon improves the tolerance to water-deficit stress induced by polyethylene glycol in wheat (Triticum aestivum L.) seedlings. J. Plant Growth Regul., 29, 106-115.

Phu, D. V., Du, B. D.,Tuan, L. N. A.,Tam, H. V. and Hien, N. Q. (2017) Preparation and Foliar Application of Oligochitosan - Nanosilica on the Enhancement of Soybean Seed Yield. Inter. J. Environ. Agri. Biotech., 2(1), 421-428.

Razzaq, A., Ammara, R., Jhanzab, H.M., Mahmood, T., Hafeez, A. and Hussain, S.(2016) A novel nanomaterial to enhance growth and yield of wheat. $J$. Nanosci. Tech., 2(1), 55-58.
Robert, A. (1995) Identification of essential oils by gas chromatography mass spectrometry. Allard Pub., USA.

Salama, H. (2012) Effects of silver nanoparticles in some crop plants, Common bean (Phaseolus vulgaris L.) and corn (Zea mays L.), Int. Res. J. Biotech., 3, 190-197.

Saqib, M., Zoerb, C. and Schubert, S. (2008) Siliconmediated improvement in the salt resistance of wheat (Triticum aestivum) results from increased sodium exclusion and resistance to oxidative stress. Funct. Plant Biol., 35, 633-639.

Sharma, P., Bhatt, M. D.,Zaidi, M.G.H., Saradhi, P. P.,Khanna, P.K. and Arora, S. (2012) Silver nanoparticle-mediated enhancement in growth and antioxidant status of Brassica juncea. Appl. Biochem. Biotechnol. 167, 2225-2233.

Siddiqui, M. H. and Al-Whaibi, M.H. (2014) Role of nano- $\mathrm{SiO}_{2}$ in germination of tomato (Lycopersicumesculentum seeds Mill.). Saudi J. Bio. Sci., 21,13-17.

Snedecor, G. W and Cochran, W .G (1980) Statistical Methods, Seventh Edition (Ames, IA: The Iowa State University Press), Seventh ed. ed. Iowa, USA.

Vashisth, A. and Nagarajan, S. (2010) Effect on germination and early growth characteristics in sunflower (Helianthus annuus) seeds exposed to static magnetic field. J. Plant Physio.,167, 149156.

Wang, L., Yang, C. and Tan, W. (2005) Dualluminophore-doped silica NPs for multiplexed signaling., Nano Letters, 5(1), 37-43.

Wettstein, D. (1957) Chlorophyll lethal faktoren under submikroskopoch for mvechsel der plastid. Exp. Cell. Res., 12, 427-433.

Woolhouse, H.W. (1984) The biochemistry and regulation of senescence in chloroplasts. Can. J. Bot., 62, 934-2942.

Yang, F. and Hong, F.S. (2006) Influence of nanoanatase Tio2 on the nitrogen metabolism of growing spinach. Biol. Trace Element Res., 110, 179-190.

Yousefzadeh,S. and Sabaghni, N. (2016) Nano-iron fertilizer effects on some plant traits of dragonhead (Dracocephalum moldavica L) under different sowing densities. Acta agric. Slovenica., 107 (2), $429-437$.

Zhang, M.,Gao, B. , Chen, J. and Li, Y. (2015) Effects of graphene on seed germination and seedling growth. J. Nanopart. Res., 17(78),1-8.

Zheng, L., Hong, F., Lu, S.and Liu, C. (2005) Effect of nano. Tio2 on strength of naturally aged seeds and growth of spinach. Biol. Trace. Elem. Res. J., 104, 83-91.

J. Sus. Agric .Sci. 44, No.1 (2018) 
Zuverza-Mena, N., Armendariz, R., Peralta-Videa, J. R. and Gardea-Torresdey, J. L. (2016) Effects of Silver Nanoparticles on Radish Sprouts: Root Growth Reduction and Modifications in the Nutritional Value. Frontiers in Plant Science, 7, 90.http://doi.org/10.3389/fpls.2016.00090.

(Received:28/12/2017;

accepted:5/2/2018 )

\section{استجابة نبات الينسون للنانوجر افيت والنانوسيليكا \\ فردوس منيسى ، مجدى خلف الله ، ناهد ر اشدو أحمد معاطى}

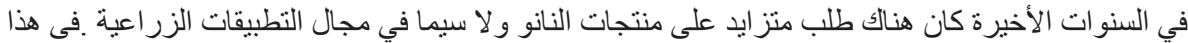

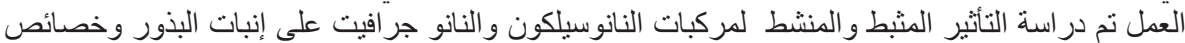

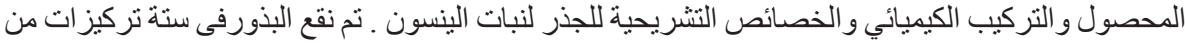

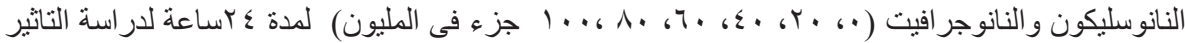

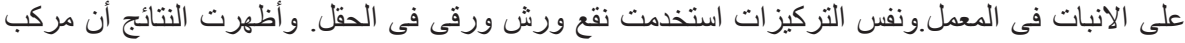

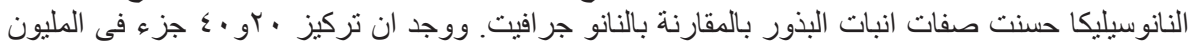

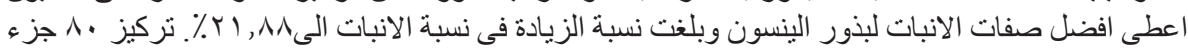

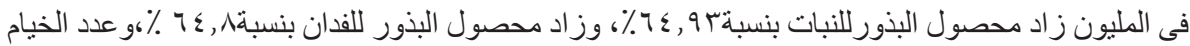

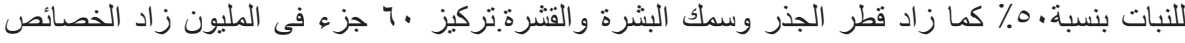

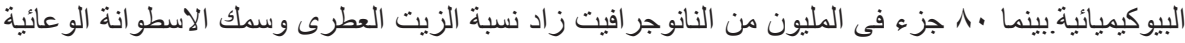

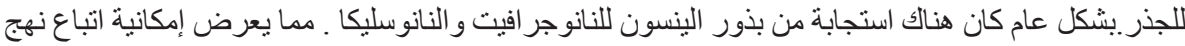
جديد للتغلب على مشاكل إنبات البذور وزيادة نسبة الزيت. 